\title{
Rapid Changes in D1 and D2 Dopamine Receptor Binding in Striatal Subregions after a Single Dose of Phencyclidine
}

\author{
Victoria S. Dalton ${ }^{1,2}$, Katerina Zavitsanou ${ }^{1,2}$ \\ 'Schizophrenia Research Institute, ${ }^{2}$ ANSTO LifeSciences, Australian Nuclear Science and Technology Organisation, Sydney, Australia
}

\begin{abstract}
Objective: In humans, a single exposure to phencyclidine (PCP) can induce a schizophrenia-like psychosis which can persist for up to two weeks. In rats, an acute dose of PCP increases dopaminergic activity and causes changes in dopamine related behaviours some of which are sexually dimorphic. To better understand the effects of PCP on dopamine receptor adaptations in the short term we examined dopamine D1-like receptors (D1R) and D2-like receptors (D2R) in the mesolimbic and nigrostriatal dopamine pathways, 4 hours after exposure to PCP in female rats.

Methods: Animals received a single dose of $40 \mathrm{mg} / \mathrm{kg} \mathrm{PCP}$ and were sacrificed 4 hours later. In vitro autoradiography was carried out using $\left[{ }^{3} \mathrm{H}\right] \mathrm{SCH} 23390$ and $\left[{ }^{3} \mathrm{H}\right]$ raclopride that target D1R and D2R respectively, in cryostat brain sections.

Results: Two way analysis of variance (ANOVA), revealed an overall effect of PCP treatment $(F[1,63]=9.065 ; p=0.004)$ on $D 1 R$ binding with an $18 \%$ decrease $(p<0.01)$ in binding in the medial caudate putamen. PCP treatment also had an overall effect on D2R binding ( $F[1,47]=5.450 ; p=0.024)$ and a trend for an increase in D2R binding across all the brain regions examined. Conclusion: These results suggest opposing D1R and D2R adaptations in striatal subregions of female rats following acute exposure to PCP that may occur through indirect mechanisms.
\end{abstract}

KEY WORDS: Phencyclidine; PCP; Dopamine; Acute; Rats; Autoradiography.

\section{INTRODUCTION}

Phencyclidine (PCP) is an N-methyl-D-aspartate (NMDA) receptor antagonist that was first developed as an anaesthetic but is now a widely abused street drug. ${ }^{1,2)}$ It induces a schizophrenia-like syndrome in normal individuals and a single exposure to PCP can lead to psychosis in humans lasting up to two weeks. ${ }^{3,4)}$ PCP has proved a valuable resource for modelling behaviours relevant to some symptoms of schizophrenia in laboratory animals. Understanding the neurochemical alterations underlying the behavioural changes that take place following PCP exposure may therefore have possible relevance to the pathophysiology associated with psychosis and schizophrenia.

In rodents, a single dose of $\mathrm{PCP}$ induces a range of dopamine related behaviours such as hyperlocomotion, cata-

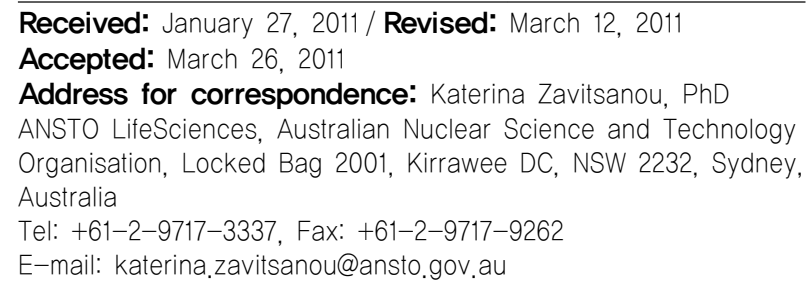

leptic freeze, stereotyped behaviour and deficits in the sensory gating measure- prepulse inhibition. ${ }^{5-10)}$ It also induces deficits in learning and memory in the rat, cat and rhesus monkey. ${ }^{1,11)}$ In rats treated with various doses of PCP $(19.5,32.6,54.4 \mathrm{mg} / \mathrm{kg})$, stereotypy and cataleptic freeze has been shown to reoccur for up to 21 days after the single dose administration. ${ }^{\text {) }}$

PCP is thought to act as an indirect agonist of dopamine and alterations in the dopaminergic system are thought to be one of the underlying neurochemical substrates for PCP induced behaviour. ${ }^{2,8)}$ Indeed, PCP treatment has been shown to increase levels of dopamine and its metabolites such as DOPAC and HVA, in the striatum, nucleus accumbens and medial prefrontal cortex in the rodent ${ }^{7,9,12,13)}$ and primate brain. ${ }^{12)}$ In addition, PCP induced behaviours can be attenuated or blocked by a range of D1 and D2 dopamine receptor antagonists. ${ }^{10,14-16)}$ Few studies however have examined short term changes that occur in dopamine receptor systems following PCP exposure particularly in the female rat brain ${ }^{17)}$ despite reported sexual dimorphism in some metabolic and behavioural responses to PCP treatment. ${ }^{18-20)}$

In the current study, we investigated whether rapid alterations occur in dopamine receptors shortly after PCP 
exposure, in female rats. We examined brain regions targeted by the mesolimbic dopamine pathway (ventral tegmental area to accumbens and olfactory tubercle) since dysregulation of dopamine in these regions is believed to lead to psychosis, particularly the positive symptoms of schizophrenia. ${ }^{21)}$ We also looked at brain regions that are targeted by the nigrostriatal pathway (substania nigra to striatum), which is important in the control of movement and locomotion that are affected by PCP. ${ }^{6)}$ In vitro autoradiography was carried out using $\left[{ }^{3} \mathrm{H}\right] \mathrm{SCH} 23390$ and $\left[{ }^{3} \mathrm{H}\right]$ raclopride to examine dopamine D1-like receptor (D1R) and D2-like receptor (D2R) binding respectively, 4 hours after a single administration of PCP.

\section{METHODS}

\section{Animals and PCP Treatment}

All experiments were carried out in accordance with the University of Wollongong Animal Care Ethics Committee guidelines, which follow the National Health and Medical Research Council guidelines for animal experimentation. All efforts were made to minimise animal suffering. Female Sprague-Dawley rats (228-270 g) were obtained from the Animal Resources Centre (Perth, WA, Australia). The animals were kept at a constant temperature of $22 \pm 2^{\circ} \mathrm{C}$ on a $12-12 \mathrm{~h}$ light-dark cycle and were allowed 1 week to acclimatise prior to the experiment. Food and water were freely available. The day of PCP treatment, rats were randomised and divided into one control group that received saline vehicle and one treated group that received PCP $(40 \mathrm{mg} / \mathrm{kg}$, i.p.). Both groups were decapitated under carbon dioxide anaesthesia $4 \mathrm{~h}$ post injection. Brains were removed and frozen in isopentane. Coronal brain sections $(20 \mu \mathrm{m})$ were cut with a cryostat and thaw mounted onto gelatinised microscope slides. Consecutive sections (six per slide) were taken from two brain compartments corresponding to plates $12-15$ and 28-35 from a standard brain atlas. ${ }^{22}$

\section{In vitro Autoradiography}

Experiments were conducted using a single saturating concentration of the radioligands, approximately 2-3 times the $\mathrm{Kd}$, (Kds for $\left[{ }^{3} \mathrm{H}\right] \mathrm{SCH} 23390$ and $\left[{ }^{3} \mathrm{H}\right]$ raclopride $1 \mathrm{nM}^{23)}$ and $1.05 \mathrm{nM}^{24)}$ respectively) which gives a good approximation of radioligand binding sites in tissue sections. ${ }^{25)} \mathrm{D}_{1}$ receptor binding was carried out according to established methods ${ }^{4,26)}$ with minor modifications. Slides were preincubated for $10 \mathrm{~min}$ at room temperature in a buffer containing $120 \mathrm{mM} \mathrm{NaCl}, 5 \mathrm{mM} \mathrm{KCl}, 2.5 \mathrm{mM}$
$\mathrm{CaCl}_{2}, 1 \mathrm{mM} \mathrm{MgCl}, 50 \mathrm{mM}$ Tris $\mathrm{HCl}$ (pH 7.4). Sections were incubated in the same buffer with the addition of 2-3 nM $\left[{ }^{3} \mathrm{H}\right] \mathrm{SCH} 23390$ (specific activity $85.0 \mathrm{Ci} / \mathrm{mmol}$, Perkin Elmer, USA) and $5 \mu \mathrm{M}$ ketanserin for $60 \mathrm{~min}$ at room temperature. Non-specific binding was determined by incubating adjacent sections in the same incubation solution in the presence of $10 \mu \mathrm{M}$ SKF 38393. Sections were then washed twice in ice cold buffer for $1 \mathrm{~min}$ followed by a dip in ice cold distilled water and dried.

The procedure for $\mathrm{D}_{2}$ receptor binding was performed according to established protocols ${ }^{26-28)}$ with minor modifications. Slides were pre-incubated at room temperature for $20 \mathrm{~min}$ in a buffer containing $120 \mathrm{mM} \mathrm{NaCl}, 2 \mathrm{mM}$ $\mathrm{CaCl}_{2}, 1 \mathrm{mM} \mathrm{MgCl} 2,50 \mathrm{mM}$ Tris $\mathrm{HCl}$ (pH 7.4). Sections were then incubated in the same buffer with the addition of 3-4 $\mathrm{nM}\left[{ }^{3} \mathrm{H}\right]$ raclopride (specific activity $62.2 \mathrm{Ci} / \mathrm{mmol}$, Perkin Elmer, USA) for $60 \mathrm{~min}$ at room temperature in the absence or presence of $10 \mu \mathrm{M}$ butaclamol to determine the total and the non-specific binding respectively. Post incubation, sections were washed $(2 \times 5 \mathrm{~min})$ in ice cold buffer and dipped in ice-cold distilled water and then dried.

Following the assay, dried sections were apposed to Kodak Biomax MR film, together with autoradiographic standards $\left({ }^{3} \mathrm{H}\right]$ microscales from Amersham), in x-ray film cassettes. Films were exposed for 36 and 70 days for $\left[{ }^{3} \mathrm{H}\right] \mathrm{SCH} 23390$ and $\left[{ }^{3} \mathrm{H}\right]$ raclopride respectively. Films were then developed using Kodak GBX developer and fixed with Kodak GBX fixer.

\section{Quantitative Analysis of Autoradiographic Images}

All films were analyzed by using a computer-assisted image analysis system, Multi-Analyst, connected to a GS-690 Imaging Densitometer (Bio-Rad, USA). As detailed in Fig. 1, brain regions quantified included the lateral and medial caudate putamen, nucleus accumbens and the olfactory tubercle. $\left[{ }^{3} \mathrm{H}\right] \mathrm{SCH} 23390$ binding was also quantified in the substantia nigra (Fig. 2). Quantification of receptor binding in each brain region was performed by measuring the average optical density in six adjacent brain sections (three for the total binding and three for the non-specific binding). Non-specific binding was subtracted from the total binding to determine the specific binding. Optical density measurements for specific binding were then converted into fmoles $\left[{ }^{3} \mathrm{H}\right] \mathrm{SCH} 23390$ or $\left[{ }^{3} \mathrm{H}\right]$ raclopride per mg tissue equivalent ( $\mathrm{fmol} / \mathrm{mg} \mathrm{TE}$ ), according to the calibration curve obtained from the tritium standards. 


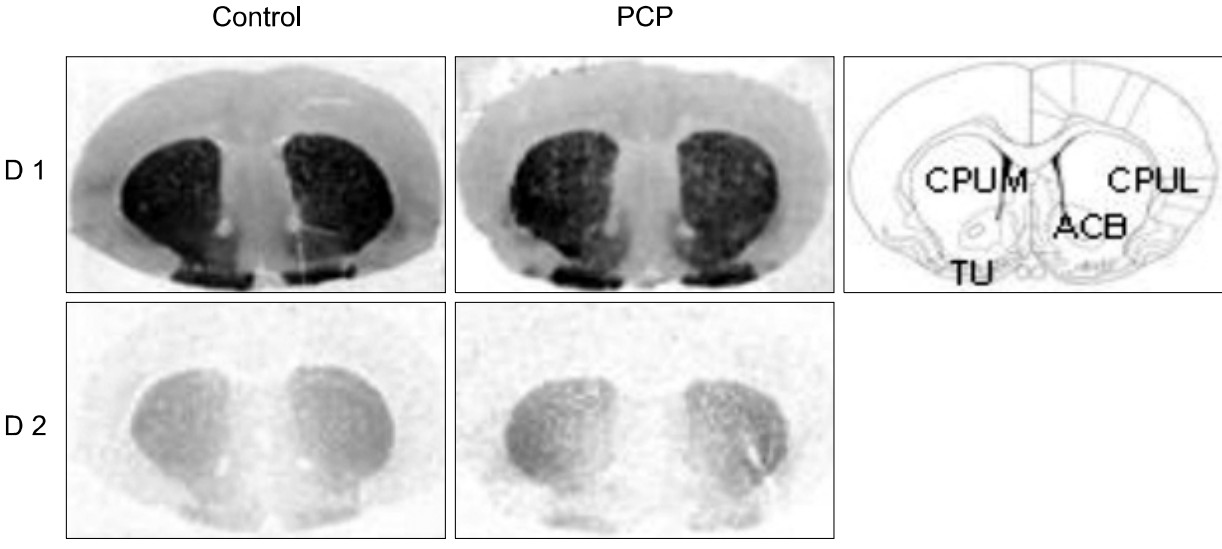

Fig. 1. Typical autoradiographs showing binding of the D1 and D2 receptor ligands, $\left({ }^{3} \mathrm{H}\right) \mathrm{SCH} 23390$ and $\left({ }^{3} \mathrm{H}\right)$ raclopride respectively in control and PCP treated female rats. Line diagram showing brain regions is adapted from Paxinos and Watson (1997). PCP, phencyclidine: ACB, nucleus accumbens; CPUL, lateral caudate putamen; CPUM, medial caudate putamen; TU, olfactory tubercle nucleus.

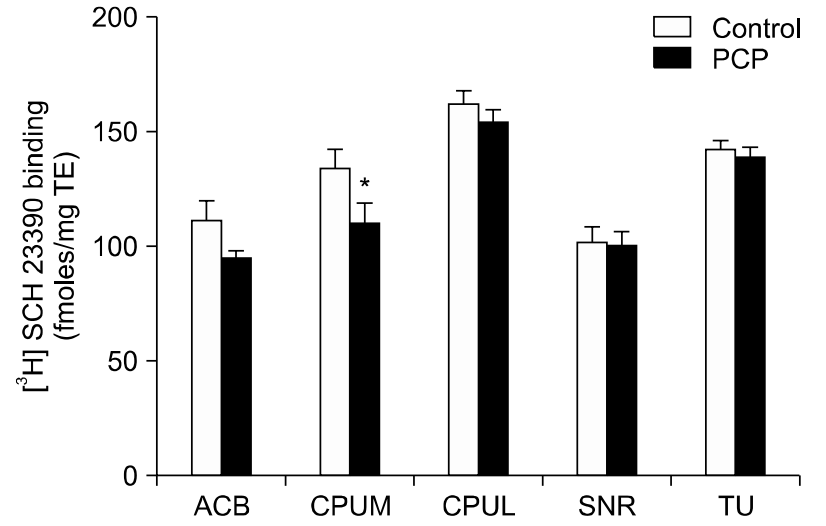

Fig. 2. $\left({ }^{3} \mathrm{H}\right) \mathrm{SCH} 23390$ binding in fmoles/mg tissue equivalent (TE) in female rats treated with vehicle or PCP. ${ }^{*} p<0.01$ in LSD post hoc tests ( $n=5-7$ per group) after two way ANOVA (treatment $x$ region). SNR, substantia nigra. See Fig. 1 for other abbreviations.

\section{Statistical Analysis}

$\left[{ }^{3} \mathrm{H}\right] \mathrm{SCH} 23390$ or $\left[{ }^{3} \mathrm{H}\right]$ raclopride binding densities were analysed for significant population outliers ( $\pm 2 \mathrm{SD})$. Two way analysis of variance (ANOVA) was carried out to identify statistically significant variation in radioligand binding with treatment status (PCP treated versus controls) and brain regions as factors. LSD post hoc tests were performed to compare binding within the various brain regions examined. Data was analyzed using the PASW Statistics 18.0 for Windows (IL, USA). Differences were regarded as statistically significant if $p<0.05$.

\section{RESULTS}

Two way ANOVA revealed a statistically significant overall variation in $\left[{ }^{3} \mathrm{H}\right] \mathrm{SCH} 23390$ binding with $\mathrm{PCP}$ treatment $(\mathrm{F}[1,63]=9.065, p=0.004)$ and brain region $(\mathrm{F}$ $[4,63]=30.323, p<0.0001)$. A significant interaction between these two variables was not found. Post hoc tests re-

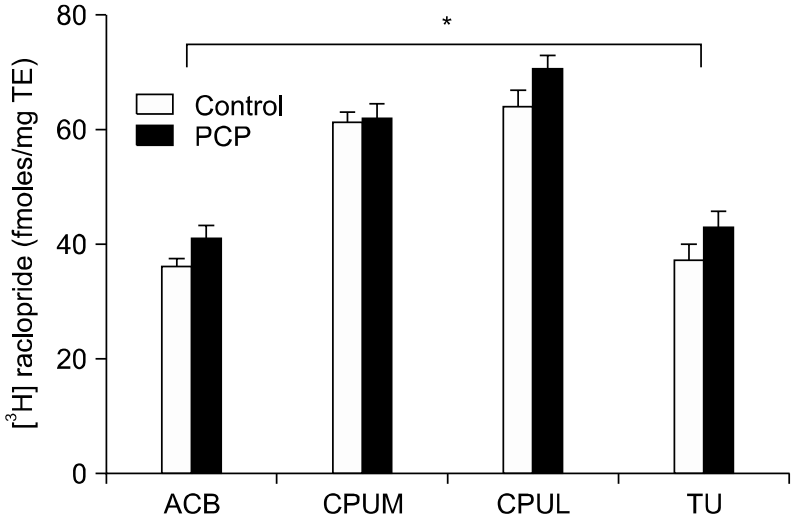

Fig. 3. $\left({ }^{3} \mathrm{H}\right)$ raclopride binding in fmoles/mg tissue equivalent (TE) in female rats treated with vehicle or PCP. *Statistically significant effect of treatment revealed by two way $\operatorname{ANOVA}(F(1,47)=5.450$, $p=0.024$ ). See Fig. 1 for abbreviations.

vealed a statistically significant $18 \%(p=0.008)$ decrease in $\left[{ }^{3} \mathrm{H}\right] \mathrm{SCH} 23390$ binding in the medial caudate putamen (Fig. 1, 2). The decrease in $\left[{ }^{3} \mathrm{H}\right] \mathrm{SCH} 23390$ binding in the nucleus accumbens $(15 \%)$ also approached significance $(p=0.055)$.

Statistical analysis revealed significant variation in $\left[{ }^{3} \mathrm{H}\right]$ raclopride binding with treatment $(\mathrm{F}[1,47]=5.450$, $p=0.024)$ and brain region $(\mathrm{F}[3,47]=64.307, p<0.0001)$. A significant interaction between treatment and region was not found. Post hoc tests did not detect any statistically significant individual changes in binding in brain region or treatment group (Fig. 1,3) although the increase in the lateral caudate putamen approached significance $(p=0.086)$. These results indicate that non-significant increases in $\left[{ }^{3} \mathrm{H}\right]$ raclopride binding (medial caudate putamen $=0.75 \%$; lateral caudate putamen $=10 \%$; nucleus accumbens $=13 \%$; olfactory tubercle $=15 \%$ ) occurred in the regions assessed in PCP treated rats compared to controls, the sum of these changes resulting in the 
significant, region-wide effect of PCP treatment on $\left[{ }^{3} \mathrm{H}\right]$ raclopride binding. ${ }^{29)}$

\section{DISCUSSION}

The main findings of the current study are that acute treatment with PCP is associated with $18 \%$ decrease in D1R binding in the medial caudate putamen and a significant overall increase in D2R binding in the female rat brain, 4 hours after exposure.

Our results are in agreement with a previous study conducted in male rats in which D1R and D2R levels were examined in the 2 hour period after exposure to PCP. ${ }^{17)}$ Tomić et al. ${ }^{17)}$ reported decreases following PCP treatment in $\left[{ }^{3} \mathrm{H}\right] \mathrm{SCH} 23390$ binding of $25 \%$ and $33 \%$ in the striatum and nucleus accumbens. Using the D2R antagonist, $\left[{ }^{3} \mathrm{H}\right]$ spiperone, they also reported an increase in D2R binding in the striatum. Despite sexual dimorphism reported for some of the metabolic ${ }^{19)}$ and behavioural effects of $\mathrm{PCP}^{18,19)}$ it appears that the effects of acute PCP treatment on dopamine receptor binding density are similar in the male $\mathrm{e}^{17)}$ and female rat brain (our study).

The changes in dopamine receptor binding levels observed in the current study reflect opposing D1R and D2R adaptive responses to receptor stimulation. ${ }^{3)}$ PCP is thought to act as an indirect agonist of dopamine. ${ }^{2,8)} \mathrm{D} 1 \mathrm{Rs}$ are postsynaptically located where their activation generally leads to an excitatory neuronal response. ${ }^{30,31)}$ The significant decrease in D1R levels observed in the medial caudate putamen accompanied by non-significant decreases in the lateral caudate putamen and accumbens following acute PCP treatment probably reflects an adaptive downregulation in response to a drug-induced increase in dopamine levels in these regions. ${ }^{3,7,9,12,13)}$ This interpretation should however be treated with caution as an in vivo study in rats reported decreased $\left[{ }^{3} \mathrm{H}\right] \mathrm{SCH} 23390$ binding in the striatum following dopamine depletion. ${ }^{32)}$ In addition Kobayashi and Inoue ${ }^{33)}$ looking at the acute effects of MK-801 (another NMDA receptor antagonist) in male mice using vivo administration of $\left[{ }^{3} \mathrm{H}\right] \mathrm{SCH} 23390$ (via the tale vein) in combination with ex vivo liquid scintillation detection, reported increased striatal $\left[{ }^{3} \mathrm{H}\right] \mathrm{SCH}$ 23390 binding. $^{33)}$

D2Rs are not only postsynaptically located like D1Rs but they are also found on dopamine cell bodies where they act as autoreceptors regulating the firing rate of DA neurons. ${ }^{31)}$ As mentioned above, PCP increases levels of dopamine in the brain therefore the increase in $\mathrm{D} 2 \mathrm{R}$ levels observed in the current study may reflect a compensatory upregulation of the $\mathrm{D} 2$ autoreceptor in order to counteract the dopaminergic hyperactivity induced by PCP treatment. ${ }^{31)}$ In contrast to our study however an in vivo PET imaging study in female baboons reported small decreases in $[11 \mathrm{C}]$ raclopride binding in the striatum after a range of doses of PCP. ${ }^{34)}$ The discrepancies between our study and results reported in the literature for both D1R and D2R binding may reflect methodological differences, type and dose of antagonist used as well as species or gender differences. More detailed observations on the effects of NMDA receptor antagonism on brain dopamine receptors and how they are affected by dose, animal species or gender, are required to reach a consensus.

In the same cohort of animals used is this study, previously we have shown that acute exposure to PCP is associated with a marked decrease in AMPA receptor levels in cortical and limbic brain regions ${ }^{35)}$ suggesting that PCP produces a prominent disruption of glutamatergic function in these regions. It is possible that acute changes in AMPA and dopamine receptors levels after PCP treatment are related since it has been shown that AMPA receptor activity influences dopamine release in the nucleus accumbens. ${ }^{36)}$

Interestingly, the adaptive responses induced by acute PCP exposure observed in the current study mirror some changes that are observed in dopamine receptor levels in schizophrenic patients. PET and SPECT studies for example have revealed that schizophrenic patients show a $10-20 \%$ elevation in the density of the D2R (one of the main targets for antipsychotic drugs) in the striatum compared to controls, independent of the effects of antipsychotics. ${ }^{37)}$ Alterations in D1R levels are also associated with cognitive impairments and negative symptoms in schizophrenia. ${ }^{37)}$ The results of imaging studies however are still inconclusive with reports of reduced, unchanged and elevated D1R levels from various studies. ${ }^{37)}$

Our findings indicate that rapid changes occur in the dopaminergic system in the female rat brain following acute PCP exposure and may help to elucidate the underlying mechanisms by which a single PCP exposure causes psychotic symptoms in normal individuals. Based on our findings and those of Tomić et al., ${ }^{17)}$ the acute effects of $\mathrm{PCP}$ on D1R and D2R binding are similar in male and female rats.

\section{- Acknowledgments}

This study was supported by an Australian Institute of Nuclear Science and Engineering (AINSIE) award to KZ and the Schizophrenia Research Institute (SRI), utilizing 
infrastructure funding from NSW Health.

\section{REFERENCES}

1. Javitt DC, Zukin SR. Recent advances in the phencyclidine model of schizophrenia. Am J Psychiatry 1991;148:13011308.

2. Steinpreis RE. The behavioral and neurochemical effects of phencyclidine in humans and animals: some implications for modeling psychosis. Behav Brain Res 1996;74:45-55.

3. Creese I, Sibley DR. Receptor adaptations to centrally acting drugs. Annu Rev Pharmacol Toxicol 1981;21:357391.

4. Dawson TM, Gehlert DR, McCabe RT, Barnett A, Wamsley JK. D-1 dopamine receptors in the rat brain: a quantitative autoradiographic analysis. J Neurosci 1986;6:2352-2365.

5. Geyer MA, Krebs-Thomson K, Braff DL, Swerdlow NR. Pharmacological studies of prepulse inhibition models of sensorimotor gating deficits in schizophrenia: a decade in review. Psychopharmacology (Berl) 2001;156:117-154.

6. Haggerty GC, Forney RB, Johnson JM. The effect of a single administration of phencyclidine on behavior in the rat over a 21-day period. Toxicol Appl Pharmacol 1984;75:444-453.

7. Hertel P, Mathé JM, Nomikos GG, Iurlo M, Mathé AA, Svensson TH. Effects of D-amphetamine and phencyclidine on behavior and extracellular concentrations of neurotensin and dopamine in the ventral striatum and the medial prefrontal cortex of the rat. Behav Brain Res 1995;72: 103-114.

8. Jentsch JD, Roth RH. The neuropsychopharmacology of phencyclidine: from NMDA receptor hypofunction to the dopamine hypothesis of schizophrenia. Neuropsychopharmacology 1999;20:201-225.

9. Steinpreis RE, Salamone JD. The role of nucleus accumbens dopamine in the neurochemical and behavioral effects of phencyclidine: a microdialysis and behavioral study. Brain Res 1993;612:263-270.

10. Tsutsumi T, Hirano $M$, Matsumoto $T$, Nakamura $K$, Hashimoto $\mathrm{K}$, Hondo $\mathrm{H}$, et al. Involvement of dopamine D1 receptors in phencyclidine-induced behavioral stimulation in rats. Clin Neuropharmacol 1995;18:64-71.

11. Frederick DL, Gillam MP, Allen RR, Paule MG. Acute behavioral effects of phencyclidine on rhesus monkey performance in an operant test battery. Pharmacol Biochem Behav 1995;52:789-797.

12. Jentsch JD, Elsworth JD, Redmond DE Jr, Roth RH. Phencyclidine increases forebrain monoamine metabolism in rats and monkeys: modulation by the isomers of HA966. $J$ Neurosci 1997; 17:1769-1775.

13. Mele A, Wozniak KM, Hall FS, Pert A. The role of striatal dopaminergic mechanisms in rotational behavior induced by phencyclidine and phencyclidine-like drugs. Psychopharmacology (Berl) 1998;135:107-118.

14. Dunn MJ, Killcross S. Clozapine, SCH 23390 and alpha-flupenthixol but not haloperidol attenuate acute phencyclidine-induced disruption of conditional discrimination performance. Psychopharmacology (Berl) 2007;190. 403-414.

15. Giannini AJ, Eighan MS, Loiselle RH, Giannini MC. Comparison of haloperidol and chlorpromazine in the treatment of phencyclidine psychosis. J Clin Pharmacol 1984;24:202-204.

16. Ogren SO, Goldstein M. Phencyclidine and dizocilpineinduced hyperlocomotion are differentially mediated. Neuropsychopharmacology 1994;11:167-177.
17. Tomić M, Vukosavić S, Joksimović J. Acute amphetamine and/or phencyclidine effects on the dopamine receptor specific binding in the rat brain. Eur Neuropsychopharmacol 1997; 7:295-301.

18. Nabeshima T, Yamaguchi K, Yamada K, Hiramatsu M, Kuwabara Y, Furukawa $\mathrm{H}$, et al. Sex-dependent differences in the pharmacological actions and pharmacokinetics of phencyclidine in rats. Eur J Pharmacol 1984;97:217-227.

19. Shelnutt SR, Gunnell M, Owens SM. Sexual dimorphism in phencyclidine in vitro metabolism and pharmacokinetics in rats. J Pharmacol Exp Ther 1999;290:1292-1298.

20. Wessinger WD. Sexual dimorphic effects of chronic phencyclidine in rats. Eur J Pharmacol 1995;277:107-112.

21. Lewis DA, Lieberman JA. Catching up on schizophrenia: natural history and neurobiology. Neuron 2000;28:325-334.

22. Paxinos G, Watson C. The Rat Brain in Stereotaxic Coordinates. 6th ed. Sydney (Australia): Academic Press; 1997.

23. Joyce JN, Lexow N, Bird E, Winokur A. Organization of dopamine D1 and D2 receptors in human striatum: receptor autoradiographic studies in Huntington's disease and schizophrenia. Synapse 1988;2:546-557.

24. Köhler C, Hall H, Ogren SO, Gawell L. Specific in vitro and in vivo binding of $3 H$-raclopride. A potent substituted benzamide drug with high affinity for dopamine D-2 receptors in the rat brain. Biochem Pharmacol 1985;34: 2251-2259.

25. Scarr E, Cowie TF, Kanellakis S, Sundram S, Pantelis C, Dean B. Decreased cortical muscarinic receptors define a subgroup of subjects with schizophrenia. Mol Psychiatry 2009;14:1017-1023.

26. Radja F, el Mansari M, Soghomonian JJ, Dewar KM, Ferron A, Reader TA, et al. Changes of D1 and D2 receptors in adult rat neostriatum after neonatal dopamine denervation: quantitative data from ligand binding, in situ hybridization and iontophoresis. Neuroscience 1993;57:635-648.

27. MacRae PG, Spirduso WW, Wilcox RE. Reaction time and nigrostriatal dopamine function: the effects of age and practice. Brain Res 1988;451:139-146.

28. Minuzzi L, Olsen AK, Bender D, Arnfred S, Grant R, Danielsen EH, et al. Quantitative autoradiography of ligands for dopamine receptors and transporters in brain of Göttingen minipig: comparison with results in vivo. Synapse 2006;59:211-219.

29. Dean B, Karl T, Pavey G, Boer S, Duffy L, Scarr E. Increased levels of serotonin $2 A$ receptors and serotonin transporter in the CNS of neuregulin 1 hypomorphic/mutant mice. Schizophr Res 2008;99:341-349.

30. Ushijima I, Carino MA, Horita A. Involvement of D1 and D2 dopamine systems in the behavioral effects of cocaine in rats. Pharmacol Biochem Behav 1995;52:737-741.

31. Viggiano D, Ruocco LA, Sadile AG. Dopamine phenotype and behaviour in animal models: in relation to attention deficit hyperactivity disorder. Neurosci Biobehav Rev 2003;27:623-637.

32. Guo N, Hwang DR, Lo ES, Huang YY, Laruelle M, Abi-Dargham A. Dopamine depletion and in vivo binding of PET D1 receptor radioligands: implications for imaging studies in schizophrenia. Neuropsychopharmacology 2003; 28:1703-1711.

33. Kobayashi K, Inoue O. An increase in the in vivo binding of $\left[^{3} \mathrm{H}\right] \mathrm{SCH} 23390$ induced by $\mathrm{MK}-801$ in the mouse striatum. Neuropharmacology 1993;32:341-348.

34. Schiffer WK, Logan J, Dewey SL. Positron emission tomography studies of potential mechanisms underlying 
phencyclidine-induced alterations in striatal dopamine. Neuropsychopharmacology 2003;28:2192-2198.

35. Zavitsanou K, Nguyen V, Newell K, Ballantyne P, Huang $\mathrm{XF}$. Rapid cortico-limbic alterations in AMPA receptor densities after administration of PCP: implications for schizophrenia. J Chem Neuroanat 2008;36:71-76.
36. Takahata R, Moghaddam B. Target-specific glutamatergic regulation of dopamine neurons in the ventral tegmental area. J Neurochem 2000;75:1775-1778.

37. Howes OD, Kapur S. The dopamine hypothesis of schizophrenia: version III-the final common pathway. Schizophr Bull 2009;35:549-562. 